\title{
CYP2A6 Gene
}

National Cancer Institute

\section{Source}

National Cancer Institute. CYP2A6 Gene. NCI Thesaurus. Code C48629.

This gene plays a role in the oxidation of nicotine to its carcinog enic metabolites. 